\title{
Agricultural waste as growing media component for the growth and flowering of Gerbera jamesonii cv. hybrid mix
}

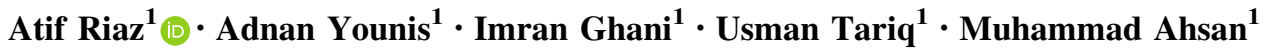

Received: 30 April 2014 / Accepted: 26 May 2015/Published online: 7 July 2015

(C) The Author(s) 2015. This article is published with open access at Springerlink.com

\begin{abstract}
Purpose This study was performed to investigate the impact of various agricultural wastes as potting media on growth, yield, and quality flower production of Gerbera jamesonii L. cv. hybrid mix, and to estimate hazardous impact of chemical fertilizers.

Method The effect of four agricultural substrates viz. farm yard manure, coconut coir dust, Lahore compost (local produce), and leaf compost combined with conventional media i.e., garden soil, sand, and silt in equal proportion was studied for commercial production of gerbera. All the treatment combinations were arranged into completely randomized design with three replicates.

Result Visible variations in morphological characters were evidenced among conventional medium and agricultural waste as substrates with significant superiority of flower quality and plant growth. The presented results showed that treatment combination of silt, coconut coir dust, and top soil (SCT) produced maximum plant height while mixture of silt, Lahore compost and top soil (SLT) gave maximum number of leaves per plant and maximum
\end{abstract}

Atif Riaz

atiff23@gmail.com

Adnan Younis

adnanyounis@uaf.edu.pk; adnanyounis1976@yahoo.com

Imran Ghani

imran_mulghani@yahoo.com

Usman Tariq

usmanflori@yahoo.com

Muhammad Ahsan

ahsan2065@gmail.com

1 Institute of Horticultural Sciences, University of Agriculture, Faisalabad 38040, Pakistan flower stalk thickness. The highest values for leaf area, number of roots, flower fresh to dry weight ratio and number of flowers per plant were achieved in combination of silt, farm yard manure, and top soil (SFT) whereas silt, sand, and top soil (SST) presented maximum flower diameter, maximum fresh, and dry weight of flowers. Chemical characteristics of growing media showed superiority of silt, farm yard manure, and top soil (SFT) and silt, sand, and top soil (STL) for available phosphorus and potassium with values of 27.0 and $500 \mathrm{ppm}$, respectively. Conclusion It was concluded that the application of waste materials in combination with silt provided positive results for vegetative and reproductive growth of Gerbera jamesonii plants.

Keywords Agricultural waste - Farm yard manure . Flower quality · Gerbera jamesonii · Leaf compost

\section{Introduction}

Gerbera (Gerbera jamesonii), is a herbaceous perennial plant with flowering stalks produced in between the leaves, ranging from 12 to $37 \mathrm{~cm}$ in height depending upon the cultivar (Weeraratne et al. 2012). Single daisy like flowers of gerbera are used for garden and home decoration in early stages but rarely used as cut flower because of their weak pedicle, bent neck, and poor vase life. The introduction of new varieties having double flowers (Torrey 1951) is considered better for cut purposes in all respects, encouraging the cut flower growers to enhance their production. It's potential as a cut flower is now widely accepted because of its ability to propagate through seed, rapid growth, and the demand for cheap labor supplies. For a better production of gerbera cut flowers, it is necessary to 
estimate all the growth factors like nutrition, growth environment, growth media, etc.

Growth media are considered among one of the most important factors affecting the production of Gerbera (Nowak and Strojny 2003; Sindhu et al. 2010; Khalaj et al. 2011; Ahmad et al. 2012). Natural soil along with peat are the most common growing substrates used for the container production of annual and perennial ornamental plants since many years (Guerrero et al. 2002; Hernandez-Apaolaza et al. 2005). In order to enhance quality and production of flowering plants chemical fertilizer are frequently applied to soils but the excessive applications of chemical fertilizers have harmful effects on soil flora, fauna, and enzymes. This ultimately leads to decrease their activity for maintaining the natural fertility of soil (Gupta et al. 2014) and increase the dependence on chemical fertilizers. As a result, there is a growing concern to reduce the application of chemical fertilizer to soils, and in order to use soil nutrients more efficiently and to overcome pollution hazards the application of organic matter is gaining acceptance among farming community.

In the past few years, usage of peat has been reduced due to environmental concerns for conservation (Abad et al. 2002). Therefore, researchers showed their interest in other organic materials like agricultural wastes which could be viable source of organic nutrients for the production of container grown plants. Agricultural waste such as rice hulls, coir, sawdust, and compost as growing media has been proved as an important substitute of simple soil for ornamental plant production (Younis et al. 2007; Wilson et al. 2009; Tariq et al. 2012) including gerbera. Furthermore, production of large sized gerbera flowers is entirely based on the structure, texture, $\mathrm{pH}$, organic matter contents, as well as nitrogen, phosphorus, and potassium levels of the growth media (Rader 1998; Lang and Pannuk 1998). Organic media that are light in weight, rich in nutrients and well-drained considered ideal choices for growth and development of flowering plants like gerbera (Awang et al. 2009; Dubey et al. 2013), as these plants are notoriously ranked as heavy feeders and require abundant quantities of plant food for maximum development. It thrives best in a media with a $\mathrm{pH}$ slightly below or above the neutral point which helps the plants to face the seasonal hazards (Abad et al. 2002).

Currently, in Pakistan less work has been carried out on this flowering plant using different growth media sources. Most of the farmers are using chemical fertilizers and peat in order to attain maximum production of flowering plants. Both ways are eco destructive in several ways and growers in Pakistan are less familiar about the usage of other organic sources for better crop production. A less expensive and more adoptable growing media from agriculture waste not only benefits the environment but also attains meaningful production outcomes for Gerbera growers. Keeping in view, environmental concerns, economic constraints, and growers need, this study was performed to investigate the impact of various agricultural wastes as potting media on morphological characters as well as yield and quality flower production of Gerbera.

\section{Materials and methods}

The comparative study for evaluation of different potting media for Gerbera jamsonii cv. Hybrid Mix plants production was conducted at Floriculture Research Area, Institute of Horticultural Sciences, University of Agriculture, Faisalabad (latitude $31^{\circ} 30^{\prime} \mathrm{N}$, longitude $73^{\circ} 10^{\prime} \mathrm{E}$ and altitude $213 \mathrm{~m}$ ). Eight-week-old seedlings were purchased from local nursery in the month of November and 108 plants of uniform size $(3 \mathrm{~cm})$ having two sets of true leaves were selected to grow in pots having different combinations of FYM, coconut coir dust, Lahore compost (local produce), sand, leaf compost, silt, and garden soil. Six treatment combinations including control were made with the similar ratio by volume (Table 1).

All treatment combinations were arranged in completely randomized design (CRD) with three replicates and six plants were planted in each replication. Management practices like irrigation, weeding, and pesticide application remained same for the all treatments.

\section{Plant growth characteristics}

Following observations on plant growth characteristics were evaluated during the course of study.

Plant height The height of plants was measured in centimeters, from base to the top leaf of the plant.

Number of leaves per plant The total number of leaves per plant was counted for each media after every 15 days.

Leaf area The leaf area $\left(\mathrm{cm}^{2}\right)$ was measured with the help of LI-3000 Portable Leaf Area Meter, USA.

Days to flower emergence Number of days were counted from the date of sowing to emergence of first flower on the plant.

Number of flowers per plant Flowers per plant were counted regularly during blooming period of the crop and then average was calculated.

Flower diameter Diameter of all the flowers was measured in centimeters $(\mathrm{cm})$ with the help of vernier caliper and average was estimated.

Flower stalk thickness Flower stalk thickness was measured in centimeters $(\mathrm{cm})$ with the help of vernier caliper and average was calculated. 
Table 1 Different treatment combinations of agricultural wastes used as growing media

\begin{tabular}{lll}
\hline Treatments & Combinations & Ratio by volume $(v: v: v)$ \\
\hline $\mathrm{T}_{0}$ & Control (garden soil $=\mathrm{GS})$ & \\
$\mathrm{T}_{1}$ & Silt + farm yard manure + top soil (SFT) & $1: 1: 1$ \\
$\mathrm{~T}_{2}$ & Silt + coconut coir dust + top soil (SCT) & $1: 1: 1$ \\
$\mathrm{~T}_{3}$ & Silt + Lahore compost + top soil (SLT) & $1: 1: 1$ \\
$\mathrm{~T}_{4}$ & Silt + sand + top soil (SST) & $1: 1: 1$ \\
$\mathrm{~T}_{5}$ & Silt + top soil + leaf compost (STL) & $1: 1: 1$ \\
\hline
\end{tabular}

Fresh weight of a flower One flower was collected at random from each plant and weighed on an electric balance (in grams) and average was computed.

Dry weight of a flower Flowers were dried in oven at $65^{\circ} \mathrm{C}$ for $48 \mathrm{~h}$, and then weighed again on electric balance. In this way, dry weight of flowers was recorded in grams and average was computed.

Fresh and dry weight ratio Fresh and dry weight ratio of a flower was calculated by dividing the fresh weight to dry weight of the flower.

Number of roots per plant The number of roots of plants was counted individually by uprooting the plant from the pots at mature stage.

\section{Chemical characteristics of growing medium}

The $\mathrm{pH}$ and Electrical conductivity (EC) in $\mathrm{dS} \mathrm{m} \mathrm{m}^{-1}$ was determined by $\mathrm{HI} 9811-5$ portable $\mathrm{pH} / \mathrm{EC} / \mathrm{TDS} /{ }^{\circ} \mathrm{C}$ meter (Mclean 1982) and digital electrical conductivity (EC) meter (Lovibond Senso Direct 150). Organic matter was determined using the method of Walkley (1947), while, available phosphorus was estimated using Spectrophotometer, model spectronic 21 USA (Olsen et al. 1954). The flame photo metric method was used for estimation of Potassium (U.S. Salinity Lab. Staff 1954).

\section{Statistical analysis}

The collected data were subjected to Fisher's analysis of variance technique (Steel et al. 1997). The Duncan's multiple range (DMR) test at $0.05 \%$ level of probability was employed to compare the differences among treatment means.

\section{Results}

\section{Plant growth characteristics}

Results regarding plant height showed significant superiority of SCT $\left(\mathrm{T}_{2}\right)$ treatment, which produced maximum plant height with $40.22 \%$ increase as compared to control $\left(\mathrm{T}_{0}\right)$ followed by 30.50 and $20.66 \%$ increase with SLT $\left(\mathrm{T}_{3}\right)$ and STL $\left(\mathrm{T}_{5}\right)$, respectively. Mean comparison of treatments in Table 2 regarding number of leaves per plant showed significant superiority of SLT $\left(\mathrm{T}_{3}\right)$ again with $34.85 \%$ increase in number of leaves followed by STL $\left(\mathrm{T}_{5}\right)$ with $30.30 \%$ more leaves, compared to minimum number of leaves (3.30) in garden soil (GS) $\left(\mathrm{T}_{0}\right)$. Therefore, maximum leaf area $\left(39.24 \mathrm{~cm}^{2}\right)$ was produced in mixture of SFT $\left(\mathrm{T}_{1}\right)$ with $164.96 \%$ increase followed by STL $\left(\mathrm{T}_{5}\right)$, SCT $\left(\mathrm{T}_{2}\right)$, and SST $\left(\mathrm{T}_{4}\right)$ with $160.50,125.79$, and $107.63 \%$ rise, respectively as compared to conventional media i.e., GS $\left(\mathrm{T}_{0}\right)$. Growing media combination in the form of STL $\left(\mathrm{T}_{5}\right)$ presented the highest value for number of roots $(6.70)$ followed by SST $\left(\mathrm{T}_{4}\right)$ and $\mathrm{SCT}\left(\mathrm{T}_{2}\right)$ treatments and finally up to $148.15 \%$ improvement over GS $\left(\mathrm{T}_{0}\right)$ was noted (Table 2).

Size of flower also improved in $\operatorname{SST}\left(\mathrm{T}_{4}\right)$ significantly with maximum increases in flower diameter $(20.75 \%)$, in comparison to all growing media used in this study. Whereas, plants grown in SCT $\left(\mathrm{T}_{2}\right)$, $\operatorname{SLT}\left(\mathrm{T}_{3}\right)$, and SFT $\left(\mathrm{T}_{1}\right)$ behaved similar in case of flower diameter (Fig. 1). The maximum flower stalk thickness was produced in $\operatorname{SLT}\left(\mathrm{T}_{3}\right)$ growth media, while the least flower stalk thickness was attained in plants grown in SCT ( $\mathrm{T}_{2}$ ) after GS (Fig. 2). The utmost but statistically similar stalk thickness obtained in SST $\left(\mathrm{T}_{4}\right)$ and STL $\left(\mathrm{T}_{5}\right)$. There was $50 \%$ improvement in flower stalk thickness in plants grown in SLT as compared to control treatment. On average, maximum fresh weight of flower with $31.87 \%$ increase in weight was attained in SST $\left(\mathrm{T}_{4}\right)$ growing media compared to control (Fig. 3). The smallest count of fresh weight of flower was observed in SFT $\left(\mathrm{T}_{1}\right)$ as this growing media caused $5.49 \%$ decrease in weight when compared with control. Similarly, results regarding dry weight of flowers showed that the SST $\left(\mathrm{T}_{4}\right)$ and SLT $\left(\mathrm{T}_{3}\right)$ gave the highest results without any significant difference. Whereas, the lowest dry weight of flowers was observed in STL $\left(\mathrm{T}_{5}\right)$ with $43.77 \%$ decrease from control (GS) (Fig. 4). The STL $\left(\mathrm{T}_{5}\right)$ mixture possessed the highest fresh to dry weight ratio, which was $104.56 \%$ greater than the control treatment, whereas minimum fresh/ dry weight ratio was produced again by GS $\left(\mathrm{T}_{0}\right)$ (see Fig. 5).

However, difference for days to flower emergence was found to be non-significant but in general, STL $\left(\mathrm{T}_{5}\right) \mathrm{mix}$ ture attained least days to first flower emergence and showed $8.30 \%$ earliness in this regard than control 
Table 2 Effect of growing substrates on plant height, number of leaves per plant, leaf area and number of roots of Gerbera jamesonii

\begin{tabular}{lllll}
\hline Treatments & Plant height $(\mathrm{cm})$ & Number of leaves per plant & Leaf area $\left(\mathrm{cm}^{2}\right)$ & Number of roots \\
\hline $\mathrm{T}_{0}$ & $7.31 \pm 0.81 \mathrm{f}$ & $3.30 \pm 0.88 \mathrm{~d}$ & $14.81 \pm 2.06 \mathrm{f}$ & $2.70 \pm 0.45 \mathrm{f}$ \\
$\mathrm{T}_{1}$ & $7.86 \pm 1.36 \mathrm{e}$ & $4.09 \pm 0.34 \mathrm{c}$ & $39.24 \pm 1.79 \mathrm{a}$ & $3.66 \pm 0.41 \mathrm{e}$ \\
$\mathrm{T}_{2}$ & $10.25 \pm 0.75 \mathrm{a}$ & $4.15 \pm 0.40 \mathrm{c}$ & $33.44 \pm 1.69 \mathrm{c}$ & $4.45 \pm 0.20 \mathrm{c}$ \\
$\mathrm{T}_{3}$ & $9.54 \pm 1.04 \mathrm{~b}$ & $4.45 \pm 0.70 \mathrm{a}$ & $30.75 \pm 2.00 \mathrm{e}$ & $4.07 \pm 0.04 \mathrm{~d}$ \\
$\mathrm{~T}_{4}$ & $8.44 \pm 0.94 \mathrm{~d}$ & $4.11 \pm 0.36 \mathrm{c}$ & $32.24 \pm 1.49 \mathrm{~d}$ & $5.79 \pm 0.03 \mathrm{~b}$ \\
$\mathrm{~T}_{5}$ & $8.82 \pm 1.32 \mathrm{c}$ & $4.30 \pm 0.75 \mathrm{~b}$ & $38.58 \pm 2.08 \mathrm{~b}$ & $6.70 \pm 0.57 \mathrm{a}$ \\
$F$ value & $1436^{* *}$ & $104^{* *}$ & $26,562^{* *}$ & $512^{* *}$ \\
$p$ value & $3.16 \times 10^{-16}$ & $1.23 \times 10^{-11}$ & $7.97 \times 10^{-24}$ & $2.13 \times 10^{-13}$ \\
\hline
\end{tabular}

$N S$ non significant, \pm SE

* Significant $(P<0.05)$

** Highly significant $(P<0.01)$

Letters (a-f) exhibit significant difference among means at $P<0.05$

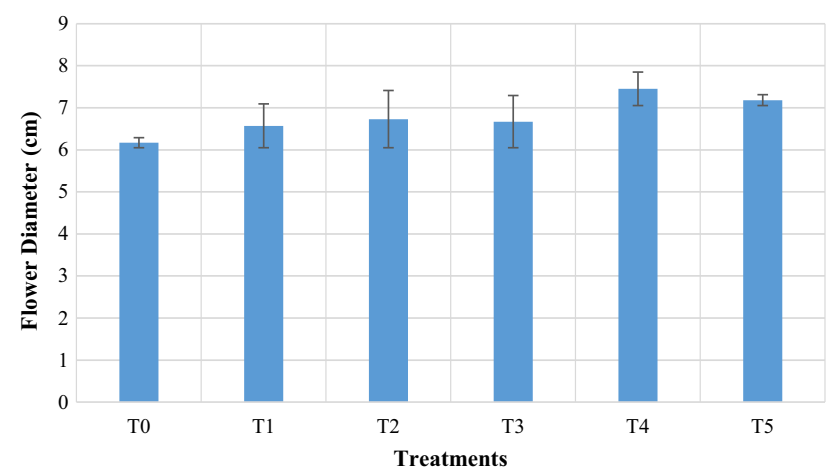

Fig. 1 Effect of different growing media on flower diameter of Gerbera jamesonii

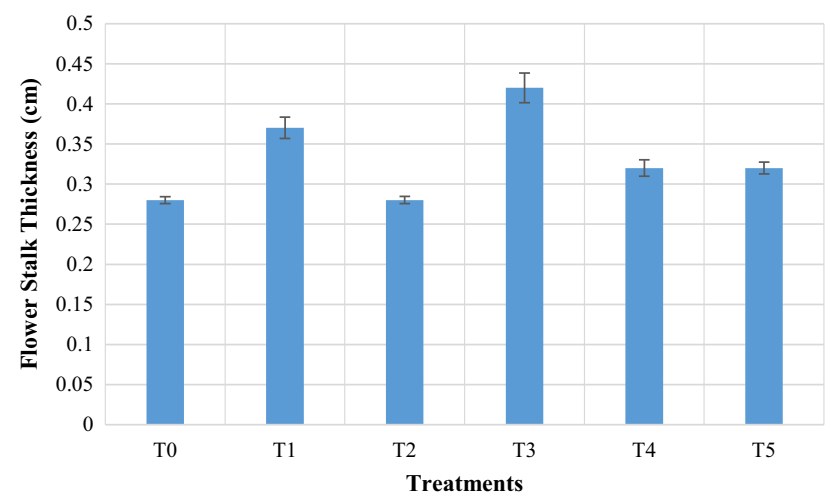

Fig. 2 Effect of different growing media on flower stalk thickness of Gerbera jamesonii

(Fig. 6). Likewise, the mixture STL $\left(\mathrm{T}_{5}\right)$ again proved the superiority $(34.85 \%)$ regarding flowers per plant over control (GS) which produced the least flowers per plant (Fig. 7). Other mixtures including SCT $\left(\mathrm{T}_{2}\right), \mathrm{SST}\left(\mathrm{T}_{4}\right)$, and SFT $\left(T_{1}\right)$ were statistically not different from each other with 23 to $30 \%$ increase in flowers per plant compared to control (GS) $\left(\mathrm{T}_{0}\right)$.

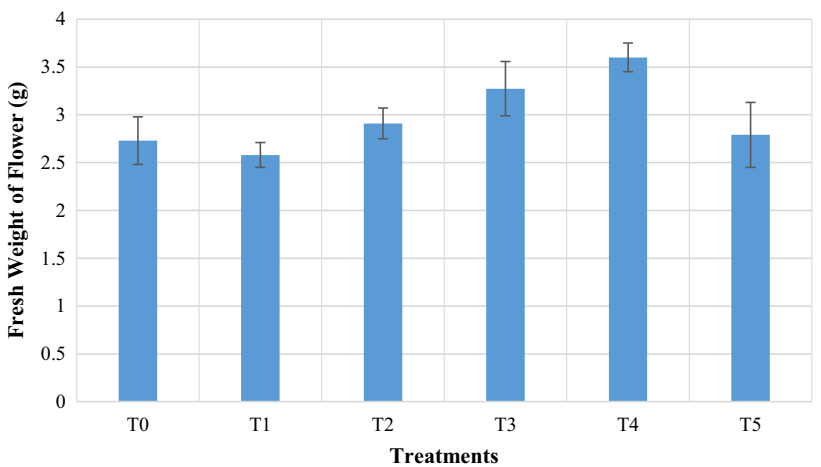

Fig. 3 Effect of different growing media on fresh weight of flower of Gerbera jamesonii

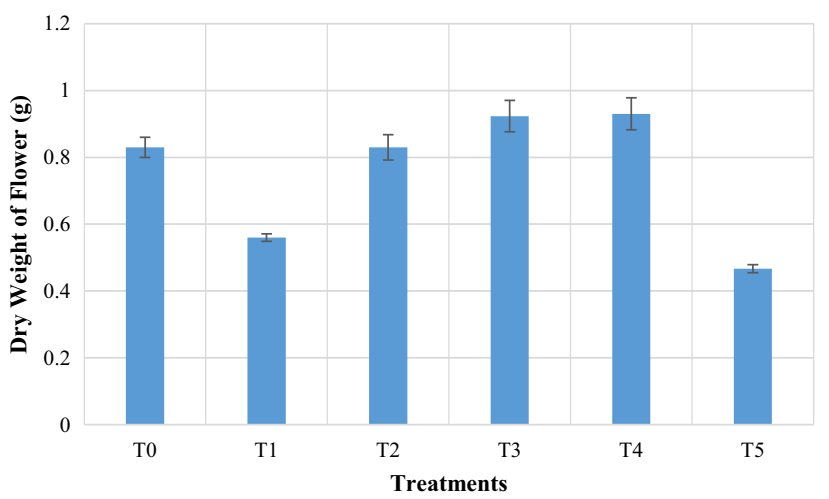

Fig. 4 Effect of different growing media on dry weight of flower of Gerbera jamesonii

\section{Chemical characteristics of growing medium}

The highly significant differences among organic matter contents, available potash $(\mathrm{K})$, available phosphorus $(\mathrm{P})$, $\mathrm{pH}$ and $\mathrm{EC}$ were observed in all the growth media used in this investigation. Growing media with SFT $\left(\mathrm{T}_{1}\right)$ combination provided better $\mathrm{P}(27 \%)$ and $\mathrm{K}(72 \%)$ contents 


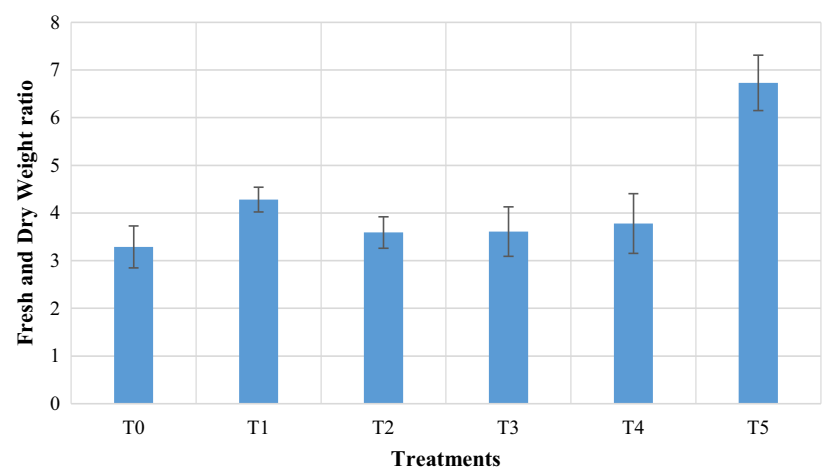

Fig. 5 Effect of different growing media on fresh and dry weight ratio of flower of Gerbera jamesonii

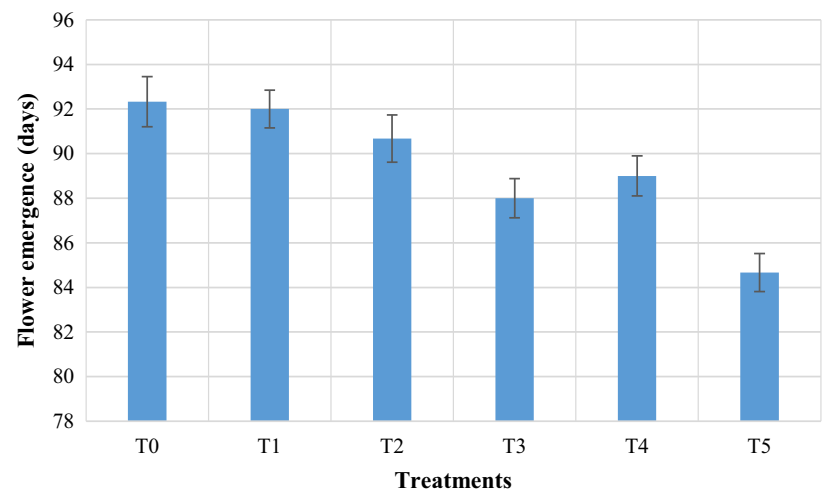

Fig. 6 Effect of different growing media on flower emergence of Gerbera jamesonii

compared to other growing media. While, maximum increase (up to $86.54 \%$ over control) in organic matter contents was found again in SFT $\left(\mathrm{T}_{1}\right)$ and STL $\left(\mathrm{T}_{5}\right)$ mixtures without any significant difference. The SCT potting media gave the least percentage of available organic matter compared to other growing media treatments. Results regarding $\mathrm{pH}$ level of growing media exhibited that GS $\left(\mathrm{T}_{0}\right)$ gave the maximum value $(9.54)$ while SST $\left(\mathrm{T}_{4}\right)$ and SFT $\left(\mathrm{T}_{1}\right)$ occupied 2 nd position. The minimum level regarding $\mathrm{pH}$ (29\% less than control) was recorded in treatment containing $\mathrm{SCT}\left(\mathrm{T}_{2}\right)$. The highest EC value $(0.73)$ with $58.70 \%$ increase over control was noticed with SFT $\left(\mathrm{T}_{1}\right)$ potting media whereas, GS $\left(\mathrm{T}_{0}\right)$ and SST $\left(\mathrm{T}_{4}\right)$ gave the lowest EC values (0.36) (see Table 3).

\section{Discussion}

Improved quality characters and growth traits of gerbera plants observed in this study with different growing substrates having garden soil, farm yard manure, coconut coir dust, a local made organic compost, and leaf compost are related to the previous findings (Saijeen et al. 2009; Ahmad

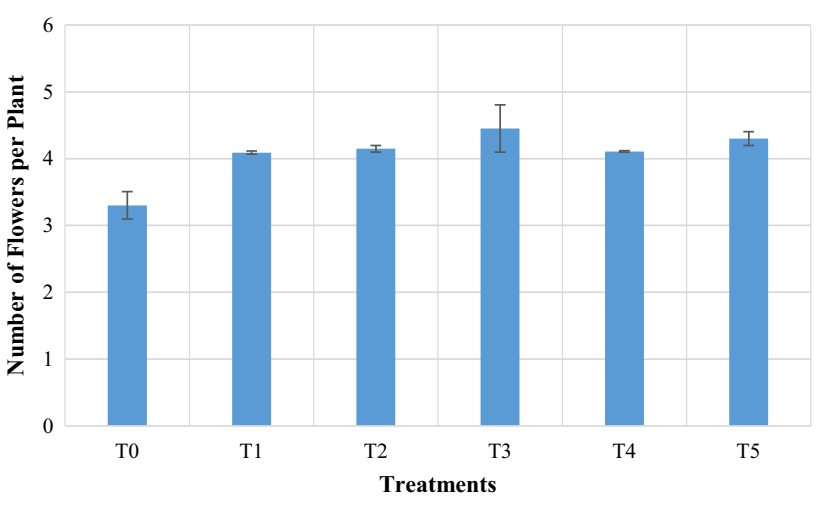

Fig. 7 Effect of different growing media on flowers per plant of Gerbera jamesonii

et al. 2012). Appropriate concentration of nutrients in conjunction with growing medium has advancing effects on best flower growth and yield.

Results exhibited in previous section showed that balanced rooting media using agricultural waste can greatly affect the plant height and are essential for attaining maximum of it. These results are in accordance with Treder (2008) and Dubsky and Sramek (2008) who reported excellent growth of perennials in leaf mold and peat substrate with the addition of rock wool and observed maximum plant height. Though, number of leaves is influenced mainly by environmental conditions, nutrients present in growth media are also one of the factors which have prime importance in this regard. More number of leaves in plants reflect good vigor and their suitability to environment and growth media. Since nitrogen in growing media significantly affects the plant growth, increase in number of leaves of plants can also be due to adequate availability of nitrogen content in growing substrate (Benito et al. 2005; Khayyat et al. 2007; Riaz et al. 2008). More number of leaves could not be considered as factor contributing toward leaf area but it is mainly due to adequate supply of nutrients. Therefore, the nutrient rich substrate can be used to achieve significant results as maximum increase in size of leaves shows adaptability of plants to soil or growth media (Cardens et al. 2006; Riaz et al. 2014). Increase in number of shoots per plant highlighted the vigorous vegetative plant growth and only nutrient-rich growing media promote such growth in plants. Above mentioned results help to conclude that growing media in a combination of STL presented the best results for the number of shoots (Bashir et al. 2007).

Results regarding number of roots reflect that treatments containing mainly leaf compost represented superiority in promoting roots number. Similar trend has also been noticed by Lopez (2006) who found that root growth of geranium, petunia, and coleus was increased as the proportion of sewage sludge plus straw compost increased up to $50 \%$ in peat. Maximum flowering as well as increase in flower bud 
Table 3 Effect of growing substrates on organic matter, available potash, available phosphorus, $\mathrm{pH}$ and EC of Gerbera jamesonii

\begin{tabular}{llllll}
\hline Treatments & Organic matter $\%$ & Available potash $(\mathrm{ppm})$ & Available phosphorus $(\mathrm{ppm})$ & $\mathrm{pH}$ & ${\mathrm{EC} \mathrm{of} \mathrm{media}\left(\mathrm{dSm}{ }^{-1}\right)}$ \\
\hline $\mathrm{T}_{0}$ & $52 \pm 1.07 \mathrm{~d}$ & $290 \pm 11.99 \mathrm{~b}$ & $21.3 \pm 0.76 \mathrm{~b}$ & $9.54 \pm 0.39 \mathrm{e}$ & $0.46 \pm 0.048 \mathrm{c}$ \\
$\mathrm{T}_{1}$ & $97 \pm 1.93 \mathrm{a}$ & $500 \pm 8.91 \mathrm{a}$ & $27 \pm 1.36 \mathrm{a}$ & $7.36 \pm 0.49 \mathrm{c}$ & $0.73 \pm 0.02 \mathrm{a}$ \\
$\mathrm{T}_{2}$ & $41 \pm 8.02 \mathrm{e}$ & $230 \pm 8.49 \mathrm{c}$ & $16.8 \pm 1.42 \mathrm{c}$ & $6.75 \pm 0.67 \mathrm{a}$ & $0.59 \pm 0.05 \mathrm{~b}$ \\
$\mathrm{~T}_{3}$ & $82 \pm 3.21 \mathrm{~b}$ & $500 \pm 13.89 \mathrm{a}$ & $15.2 \pm 1.19 \mathrm{c}$ & $6.81 \pm 0.22 \mathrm{~b}$ & $0.49 \pm 0.004 \mathrm{c}$ \\
$\mathrm{T}_{4}$ & $62 \pm 2.13 \mathrm{c}$ & $220 \pm 6.94 \mathrm{c}$ & $16.5 \pm 2.72 \mathrm{c}$ & $7.94 \pm 0.71 \mathrm{~d}$ & $0.36 \pm 0.01 \mathrm{~d}$ \\
$\mathrm{~T}_{5}$ & $93 \pm 7.01 \mathrm{a}$ & $500 \pm 10.02 \mathrm{a}$ & $25 \pm 2.02 \mathrm{a}$ & $6.82 \pm 0.1 \mathrm{~b}$ & $0.59 \pm 0.08 \mathrm{~b}$ \\
$F$ value & $1597^{* *}$ & $952^{* *}$ & $18.1 * *$ & $154^{* *}$ & $123^{* *}$ \\
$p$ value & $1.67 \times 10^{-16}$ & $3.70 \times 10^{-15}$ & $3.22 \times 10^{-05}$ & $1.88 \times 10^{-10}$ & $6.86 \times 10^{-10}$ \\
\hline
\end{tabular}

* Significant $(P<0.05)$

** Highly significant $(P<0.01), \pm \mathrm{SE}$

Letters (a-f) exhibit significant difference among means at $P<0.05$

diameter and subsequently increase in flower diameter indicates suitability of that growing medium, where organic matter in growing substrate and optimum amount of NPK manipulate plant growth and flower size (Kiran et al. 2007). Growing media containing silt and Lahore compost exhibited their superiority for stalk thickness, stem diameter, flower fresh and dry weights, and its ratio contrast to conventional media which proves that this kind of media can be used for gerbera production effectively. These results are in consistent with Grassotti et al. (2003) and Caballero et al. (2009) who observed that growing media having combination of silt + compost and manure can produce the maximum flower stalk thickness, fresh, and dry weights of gladiolus and lily. Similarly, the combination of sand, mushroom compost, coconut coir, and peat produced the best quality of plants with considerable increase in most of the growth parameters (Younis et al. 2013). Khalaj et al. (2011) also observed that maximum stem diameter of Gerbera plants attained with media in combination of perlite and peat. Rich supply of nutrients like $\mathrm{K}, \mathrm{N}$, and $\mathrm{P}$ in growing substrate is proved to be sufficient for production of good quality flowers (Younis et al. 2014) and adequate availability of these nutrients in growing media gave significant results regarding growth and flowering indices in this experiment. Organic matter and $\mathrm{P}$ content in growing substrate affected the quality of flowers as well. Growing media with excellent nutrient quality influences plant growth as availability of $\mathrm{P}$ and $\mathrm{K}$ contents in growth media has positive relationship with flowering indices. In current research, excellent nutrient quality with maximum phosphorus and potassium contents (27.00 and $500 \mathrm{ppm}$, respectively) was achieved in SFT growing media. Good quality flowers obtained in this combination is a confirmatory with Grassotti et al. (2003). Treder (2008) reported that plants had long stem, and maximum flowering in growing media with optimum $\mathrm{P}$ and $\mathrm{K}$ contents, where potting media comprising farm yard manure can give maximum amount of $\mathrm{P}$ and $\mathrm{K}$ contents (Strojny and Nowak 2004; Younis et al. 2007). Organic matter in growing media can individually promotes the plant growth due to high availability of nutrients (Fascella and Zizzo 2005; Younis et al. 2010), where maximum organic matter was found in farm yard manure containing substrates while other treatments showed no significant results. Physio-chemical attributes of high organic matter encourage the plant growth and improves substrate quality (Abad et al. 2001) which has been seen in this research work.

Various substrates having farm yard manure and compost are responsible to reduce $\mathrm{pH}$ and $\mathrm{EC}$ due to high nutrient supply (Bi et al. 2009; Diacono and Montemurro 2010). Actually, accessibility of nutrients to plants in growing media is coupled with the changes in media $\mathrm{pH}$ as increase or decrease in $\mathrm{pH}$ alters the solubility of nutrients and has direct effect on plant growth and development. Changes in $\mathrm{pH}$ above or lower than the optimum range adversely affected plants by damaging roots and decreasing nutrients availability (Altland 2006; Awang et al. 2009). The best range of dissolved salt contents i.e., EC in soil supports the better plant growth (Awang et al. 2009). Higher EC levels were not found to inhibit plant growth however; it decreased the biological activity of soil than the threshold value which negatively impacts plant growth (Miller 2001; Ribeiro et al. 2002). Suitable use of substrates for nutrient accessibility by plants not only depends upon nutrient composition but also on $\mathrm{pH}$, nutrient form, organic compounds, and adsorption capacity of the growing media due to the presence of high organic matter content, $\mathrm{P}$ and $\mathrm{K}$.

\section{Conclusion}

Results of this study indicated that application of coconut coir dust in combination with silt produced maximum plant height while addition of Lahore compost to substrate gave 
maximum number of leaves per plant and maximum flower stalk thickness. The addition of farm yard manure to silt and top soil produced maximum leaf area, highest value for number of roots, maximum fresh to dry weight ratio, and maximum flowers per plant, whereas maximum flower diameter, maximum fresh and dry weights of flower, resulted with mixture of sand with silt and top soil. All these organic waste substrates showed positive attribute to growth and flowering of gerbera with readily availability of nutrients for uptake. Therefore, it is concluded that suggested agricultural waste material can be used as growing media for better Gerbera jamesonii growth and can be explored further for other combinations.

Acknowledgments The Higher Education Commission (HEC) is highly acknowledged for providing funds for this research project.

Open Access This article is distributed under the terms of the Creative Commons Attribution 4.0 International License (http://creativecommons.org/licenses/by/4.0/), which permits unrestricted use, distribution, and reproduction in any medium, provided you give appropriate credit to the original author(s) and the source, provide a link to the Creative Commons license, and indicate if changes were made.

\section{References}

Abad M, Noguera P, Bures S (2001) National inventory of organic wastes for use as growing media for ornamental potted plant production: case study in Spain. Bioresour Technol 77:197-200

Abad M, Noguera P, Puchades R, Maquieira A, Noguera V (2002) Physico-chemical and chemical properties of some coconut dusts for use as a peat substitute for containerized ornamental plants. Bioresour Technol 82:241-245

Ahmad I, Ahmad T, Gulfam A, Saleem M (2012) Growth and flowering of gerbera as influenced by various horticultural substrates. Pak J Bot 44:291-299

Altland JE (2006) Substrate pH, a tricky topic. Digger 50:42-47

Awang Y, Shaharom AS, Mohamad RB, Selamat A (2009) Chemical and physical characteristics of cocopeat based media mixtures and their effects on the growth and development of Celosia cristata. Am J Agric Biol Sci 4:63-71

Bashir MA, Ahmad M, Anjum MA (2007) Effect of various potting media on growth of rooted jojoba (Simmondsia chinensis) cuttings. Int J Agri Biol 9:147-151

Benito M, Masaguer A, Antonio RD, Moliner A (2005) Use of pruning waste compost as a component in soil less growing media. Bioresour Technol 96:597-603

Bi L, Zhang B, Liu G, Li Z, Liu Y, Ye C, Yu X, Lai T, Zhang J, Yin J, Liang Y (2009) Long-term effects of organic amendments on the rice yields for double rice cropping systems in subtropical China. Agri Ecosyst Environ 129(4):534-541

Caballero R, Pajuelo P, Ordovas J, Carmona E, Delgado A (2009) Evaluation and correction of nutrient availability to Gerbera jamesonii $\mathrm{H}$. Bolus in various compost-based growing media. Sci Horti 122:244-250

Cardens MCA, Gomez IFR, Ronacancio VJF, Cordoba BC, Canola PW (2006) Growth analysis of standard carnation cv. 'Nelson' in different substrate. Acta Hort 718:623-630
Diacono M, Montemurro F (2010) Long-term effects of organic amendments on soil fertility. A review. Agron Sustain Dev 30:401-422

Dubey RK, Simrat-Singh Kukal SS, Kalsi HS (2013) Evaluation of different organic growing media for growth and flowering of petunia. Commun Soil Sci Plant Anal 44:1777-1785

Dubsky M, Sramek F (2008) Crushed rockwool as a component of growing substrates. Acta Hort 779:491-495

Fascella G, Zizzo GV (2005) Effect of growing media on yield and quality of soilless cultivated rose. Acta Hort 697:133-138

Grassotti A, Nesi B, Malrtta M, Magnani G (2003) Effects of growing media and planting time on lily hybrids in soilless culture. Acta Hort 603:395-399

Guerrero F, Gasco JM, Hernandez-Apaolaza L (2002) Use of pinebark and sewage sludge compost as components of substrates for Pinus pinea and Cupressus arizonica production. J Plant Nutr 25(1):129-141

Gupta R, Yadav A, Garg VK (2014) Influence of vermicompost application in potting media on growth and flowering of marigold crop. Int J Recycl Organ Waste Agri 3(1):1-7

Hernandez-Apaolaza L, Gascó AM, Gascó JM, Guerrero F (2005) Reuse of waste materials as growing media for ornamental plants. Bioresour Technol 96(1):125-131

Khalaj MA, Amiri M, Sindhu SS (2011) Study on the effect of different growing media on the growth and yield of Gerbera (Gerbera jamesonii L.). J Ornam Hortic Plants 1(3):185-189

Khayyat M, Nazari F, Salehi H (2007) Effects of different pot mixtures on pothos (Epipremnum aureum Lindl. and Andre 'Golden Pothos') growth and development. Am-Eurasian J Agric Environ Sci 2:341-348

Kiran M, Din J, Waseem K, Jilani MS, Khan MQ (2007) Effect of different growing media on the growth and development of Dahlia (Dahlia pinnata) under the agro-climatic condition of Dera Ismail Khan. Pak J Biol Sci 10:4140-4143

Lang HJ, Pannuk TR (1998) Effects of fertilizer concentration and minimum-leach drip irrigation on the growth of New Guinea Impatiens. Hort Sci 33:83-688

Lopez A (2006) Media influence on post harvest container plant quality in a retail nursery setting. Dissertation, University of Agriculture and Mechanical College, USA

McLean EO (1982) Soil $\mathrm{pH}$ and lime requirement. In: Page AL, Miller RH, Keeney DR (eds) Methods of soil analyses, part 2, chemical and microbiological properties, 2nd edn. American Society Agronomy, Madison, pp 199-224

Miller M (2001) Fulfilling special needs of nurseries. Biocycle 42:65-67

Nowak JS, Strojny Z (2003) Effect of different container media on the growth of Gerbera. Acta Hort 608:59-63

Olsen SAR, Sant MD, Gislerod HR, Solbraa K (1954) Nitrogen balance in bark composts used as growing media. Acta Hort 150:202-203

Rader JS (1998) Petunia. In: Ball V (ed) Ball Redbook. Ball Publishing, Batavia, IL, USA, pp 682-686

Riaz A, Arshad M, Younis A, Raza A, Hameed H (2008) Effects of different growing media on growth and flowering of Zinnia elegans cv. Blue point. Pak J Bot 40:1579-1585

Riaz A, Farooq U, Younis A, Karim A, Taj AR (2014) Growth responses of Zinnia to different organic media. Acta Hort 1018:565-572

Ribeiro HM, Vasconcelos E, Santos JQ (2002) Fertilization of potted geranium with municipal solid waste compost. Bioresour Technol 73:247-249

Saijeen S, Kaewman O, Suksawat M (2009) Evaluation of media, organic and chemical fertilizer applications on growth of pot gerbera (Gerbera jamesonii). Asian J Food Agro-Ind 2:S51-S56 
Sindhu SS, Gholap DB, Singh MC, Dhiman MR (2010) Effect of medium amendments on growth and flowering in gerbera. Indian J Hort 67:391-394

Steel RGD, Torrie JH, Dicky DA (1997) Principles and procedures of statistics: a biometric approach. Mc Graw Hill Inc, New York

Strojny Z, Nowak JS (2004) Effect of different growing media on the growth of some bedding plants. Acta Hort 644:157-162

Tariq U, Rehman S, Khan MA, Younis A, Yaseen M, Ahsan M (2012) Agricultural and municipal waste as potting media components for the growth and flowering of Dahlia hortensis 'Figaro'. Turk J Bot 36:378-385

Torrey JG (1951) Cambial formation in isolated pea roots following decapitation. Am J Bot 38:596-604

Treder J (2008) The effects of cocopeat and fertilization on the growth and flowering of oriental lily 'star gazer'. J Fruit Ornam Plant Res 16:361-370

U.S. Salinity Lab Staff (1954) Diagnosis and improvement of saline and alkali soils. USDA Handbook 60, Washington DC, USA

Walkley A (1947) A critical examination of a rapid method for determining organic carbon in soils. Effect of variations in digestion conditions and of organic soil constituents. Soil Sci 63:251-263
Weeraratne TP, Daundasekera WAM, Wijesundara DSA (2012) Field survey of postharvest handling of cut flowers produced in the Up country of Sri Lanka for the local market. Ceylon J Sci 41:67-70

Wilson SB, Muller KL, Wilson PC, Incer MR, Stoffella PJ, Graetz DA (2009) Evaluation of new container media for Aglaonema production. Commun Soil Sci Plant Anal 40:2673-2687

Younis A, Ahmad M, Riaz A, Khan MA (2007) Effect of different potting media on the growth and flowering of Dahlia coccinia cv. Mignon. Acta Horti 804:191-196

Younis A, Riaz A, Wasim M, Khan MA, Nadeem M (2010) Production of quality croton (Codiaeum variegatum) plants by using different growing media. Am-Eurasian J Agric Environ Sci 7:232-237

Younis A, Riaz A, Siddique MI, Lim KB, Hwang YJ, Khan MA (2013) Anatomical and morphological variation in Dracaena reflexa 'Variegata' grown in different organic potting substrates. Flower Res J 21:162-171

Younis A, Anjum S, Riaz A, Hameed M, Tariq U, Ahsan M (2014) Production of quality dahlia (Dahlia variabilis cv. Redskin) flowers by efficient nutrients management. Am-Eurasian J Agric Environ Sci 14:137-142 